\title{
Trace Metals and Organochlorine Pesticide Residues in Imported Fishes in Bangladesh and Human Health Risk Implications
}

Md. Monirul Islam

University of Dhaka: Dhaka University

Nusrat Jahan Avha

Dhaka University

Shamim Ahmed

BCSIR: Bangladesh Council of Scientific and Industrial Research

\section{Md. Ahedul Akbor}

BCSIR: Bangladesh Council of Scientific and Industrial Research

\section{Md. Sofiqul Islam}

Department of Fisheries, Government of the People's Republic of Bangladesh

\section{Farhana Mostafiz}

Dhaka University

Md. Habibullah-Al-Mamun ( $\nabla$ almamunhabib@du.ac.bd)

University of Dhaka https://orcid.org/0000-0001-9568-5361

\section{Research Article}

Keywords: Trace metals, Organochlorine pesticides, Imported fish, Health risk, Bangladesh

Posted Date: August 6th, 2021

DOI: https://doi.org/10.21203/rs.3.rs-679438/v1

License: (c) (i) This work is licensed under a Creative Commons Attribution 4.0 International License. Read Full License

Version of Record: A version of this preprint was published at Environmental Science and Pollution Research on October 19th, 2021. See the published version at https://doi.org/10.1007/s11356-021-17074-5. 


\section{Abstract}

Substantial quantity of fish has been imported to Bangladesh without adequate food safety assessment which can pose a serious health risk to local people. This study analyzed the trace metals and organochlorine pesticides residues and the associated human health risk in 33 imported fishes (9 species) from four countries (India, Myanmar, Oman and United Arab Emirates) collected from three different ports (Benapole, Bhomra, and Chittagong) of Bangladesh with invoice lists from the port authorities. Trace metal concentrations were determined using graphite furnace absorption spectrometry and flame absorption spectrometry. The two organochlorine pesticides (Aldrin and Chlordane) residues were determined by GC-MS and found as below detection level (BDL). The trace metal concentrations $(\mathrm{mg} / \mathrm{kg}-\mathrm{ww})$ in imported fish samples ranged as: As: 0.008 to $0.558 ; \mathrm{Pb}: 0.004$ to 0.070 ; $\mathrm{Cr}$ : 0.010 to $0.109 ; \mathrm{Cd}: 0.00$ to 0.083 ; Ni: 0.011 to 0.059 ; $\mathrm{Co}$ : BDL to $0.067 ; \mathrm{Mn}$ : BDL to $0.0780 ; \mathrm{Fe}: 1.780$ to 10.77 ; $\mathrm{Cu}: 0.055$ to 0.632 ; and $\mathrm{Zn:} 0.898$ to 9.245. Concentrations of As and $\mathrm{Cd}$ were higher than the food safety guideline. Considering the source country of imported fishes, fish samples from Oman were mostly contaminated by the trace metals. The estimated daily intake (EDI) was higher for As and Cr. However, the target hazard quotient (THQ) for individual metal and total THQ for combined metals were lower than 1, indicating no apparent non-carcinogenic health risk for consumers. But target cancer risk (TR) was higher for As, and Ni and the values exceeded the acceptable range indicating a high carcinogenic risk for the local people. Therefore, extensive monitoring of these toxic chemicals is needed prior to import these fishes to the country. Given the self-sufficiency in fish production this study also argues whether Bangladesh needs to import the fishes at all.

\section{Introduction}

Bangladesh is one of the dominant fish producing countries in the world as being bestowed with immense inland, coastal and marine water resources generating great potential in fisheries sector. According to the FAO, Bangladesh has ranked $3 \mathrm{rd}$ in inland open water capture production and 5th in world aquaculture production and also the fish production has increased more than five times over the last three decades (FAO, 2018). But a large amount of fish and fishery products are being imported every year to Bangladesh from India, Myanmar, Oman, Pakistan, United Arab Emirates and Yemen, whereas the country is self-sufficient in fish production according to the Department of Fisheries, Government of Bangladesh with per capita consumption per day which is about 62.58 grams against the demand of 60 grams (DoF, 2018).

In line with 2016-17 fiscal year, about 1 lakh tons of fish were imported (DoF, 2018) and from the first five months of 2016-2017 fiscal year, about 16,032 tonnes of imported fish costed about Tk 66.36 crore which is an issue of concern. Additionally, the port authority asserted that the average annual 48,000 tonnes of fishes were imported from the last four years (The Daily star, 21 January 2018, Page 11).The imported fishes were mostly Major carps, Cat fishes, Sardines, and Shads. Among these fishes, Sardines and Shads bear resemblance like Hilsa fish but the taste is not the equivalently upright. It was not evident also that from where these packages came from, but as per port sources around 90 percent of Bangladesh's fish consignment were from Myanmar, the Maldives, India and Oman and nearly half were from Oman.

BBC Bangla reported a large amount of imported fishes as was found to be in the local market of Bangladesh, e.g. Mohammadpur Bazar, Banani Bazar, etc. These frozen imported fishes were hardly identified by the buyer in the local fish market. Therefore, these foreign fish are sold referring as local fish of the country. The Bangladesh Food Safety Authority (BFSA) has articulated doubt about the quality of these imported fishes and the fact that if these fishes have been examined thoroughly as for harmful chemicals which are a major threat to public health. A report has been published on the Daily Star that the BFSA mandated to test and it found high detrimental level of heavy metals in the Chandana ilish fish which was imported (The Daily star, 21 January 2018, Page 4). However, neither BBC nor the BFSA were able to mention the exact sources of these fish when they were contacted by the authors. 
Fish are regarded as one of the most susceptible aquatic organisms to noxious chemical substances in water such as trace metals, pesticides which accumulates in them and later are magnified up in the food chain (Thiyagarajan et al., 2012). These chemical hazards are persistent and in excess amount may lead to bioaccumulation ultimately posing serious human health consequences including possible carcinogenic risks (Chen et al. 2009; Medeiros et al. 2012; Ahmed et al., 2015; Saha et al., 2016).

To import these inessential fishes a significant amount of money has been paid by the country every year superfluously. Additionally, these fishes are substandard in terms of taste and quality as compared to local fishes. Local people do not even consume some imported species, for instance, Tonguesole fish and Pony fish. Moreover, they might contain elevated level pollutants or toxic chemicals. As far no studies has been published regarding the existing level of chemical toxicants in the fishes imported to Bangladesh. So, it's a prerequisite to investigate the level of trace metals and pesticides in those imported fishes to aware the concerned authority and the general people. The main aim of this study was to determine the concentration of 10 trace metals: arsenic (As), lead (Pb), chromium ( $\mathrm{Cr}$ ), cadmium (Cd), nickel (Ni), cobalt (Co), manganese (Mn), iron (Fe), copper (Cu), and zinc ( $\mathrm{Zn}$ ) and two organochlorine pesticides (Aldrin and Chlordane) in the imported fishes in Bangladesh and to assess the associated health risk to consumers.

\section{Materials And Methods}

\subsection{Study area and sample collection}

Thirty-three imported fish specimens of nine species were collected after acquiring the permission of port authority from Benapole land port $\left(23^{\circ} 2^{\prime} 31^{\prime \prime} \mathrm{N} 88^{\circ} 53^{\prime} 44^{\prime \prime} \mathrm{E}\right)$; Bhomra land port $\left(22.35^{\circ} \mathrm{N} 89.08^{\circ} \mathrm{E}\right)$; Chittagong port $\left(22.313^{\circ} \mathrm{N} 91.800^{\circ} \mathrm{E}\right)$ (Fig. 1). As Chittagong port is the biggest and most of the products as well as fishes are imported from different countries through this port, this site was considered. Fish samples analyzed in this study were: Labeo rohita (Rui), Otolithes ruber (Tigertooth croaker), Scomber australasicus (Blue mackerel), Etrumeus acuminatus (Red-eye round herring), Arius maculatus (Spotted sea catfish), Tenualosa toli (Toli shad), Lutjanus johnii (Snapper), Eubleekeria splendens (Ponyfish), Cynoglossus cynoglossus (Tonguesole). After collecting the samples, the sampling ice box was used to keep the samples with an adequate amount of ices and transferred to INARS Laboratory, BCSIR, Bangladesh. Then the samples were washed with distilled water to avoid any possible contamination and kept in the drawer of a refrigerator wrapped with aluminum foil paper at a temperature of below $-20^{\circ} \mathrm{C}$.

\subsection{Trace Metal Analysis}

In this study, fish muscle was mainly used for determining trace metals and pesticides. Homogenized sample was used for dry ashing at low temperature first to dry the sample to prevent the sample loss and then slowly the temperature was increased as $\leq 50^{\circ} \mathrm{C}$. A high temperature muffle furnace was used which was capable of maintaining temperatures of between 500 and $600^{\circ} \mathrm{C}$ following the method of AOAC official method 999.11. In this study, the procedures of nitric acid digestion were applied. Concentrated nitric acid $(5 \mathrm{ml})$ was poured into cooled sample and was transferred to hotplate to heat at $100-180^{\circ} \mathrm{C}$. After digestion, sample was poured into the $50 \mathrm{ml}$ volumetric flask and distilled water was added up $50 \mathrm{ml}$ line very carefully. After 2-3 min the sample was filtered with Whatman ${ }^{\circledR} 90$ milli-pore size filter paper and stored for the instrumental analysis. A flame atomic absorption spectrometer (Varian AA-240FS) and a graphite atomic absorption spectrometer (Varian AA-240Z) were used for the analysis of 10 metal concentration (As, $\mathrm{Pb}, \mathrm{Cr}, \mathrm{Cd}, \mathrm{Ni}, \mathrm{Co}, \mathrm{Mn}$, $\mathrm{Fe}, \mathrm{Cu}$, and $\mathrm{Zn}$ ). Metal concentration were determined from the calibration curved obtained from standard solution.

\subsection{Pesticides Residues Analysis}

For pesticide residue analysis, $\mathrm{n}$-Hexane residue analysis grade (95\% n-hexane) and acetone residue analysis grade were used for extraction. Anhydrous sodium sulphate used as analytical reagent grade. $20 \mathrm{~g}$ of previously minced fish muscle 
was taken to a $250 \mathrm{ml}$ conical flask and $50 \mathrm{ml} \mathrm{n}$ - hexane and $50 \mathrm{ml}$ acetone were added to sample. After adding those the conical flask was placed to orbital shaker and shaked the sample at $300 \mathrm{rpm}$ for $2 \mathrm{hrs}$. Next the sample was filtered by Whatman ${ }^{\circledR}$ filter paper of 42 milli-pore to a round flask. Then the sample was concentrated to $1 \mathrm{ml}$ by a rotary evaporator to follow the SPE procedures (Chen et al. 2009). After that the concentrated sample was washed with nhexane where the proportion of sample and hexane was 1:2. Finally the sample was poured to $15 \mathrm{ml}$ centrifuge tube. In this study, sample was analyzed by Gas chromatography (Shimadzu QP 2020 series), auto injector (Shimadzu AOC 20i) and sampler were used. Mass spectrometry detector was used and helium was used as carrier gas.

\subsection{Clean up}

$10 \% \mathrm{H}_{2} \mathrm{SO}_{4}$ was prepared in a volumetric flask and approximately $1 \mathrm{~g}$ anhydrous sodium sulphate was mixed within it properly. Then about $1 \mathrm{ml}$ solution was taken from volumetric flask by pipetting and poured it to the centrifuge tube containing sample. After that the cap of centrifuge tube was put well and vortexed it on a vortex mixer at $2500 \mathrm{rpm}$ about 1-2 min. Then waited for few minutes. Then the supernatant was separated with syringe and taken into GC vial.

\subsection{Quality assurance and accuracy check}

Standard stock solution of $1000 \mathrm{mg} / \mathrm{L}$ of $\mathrm{As}, \mathrm{Pb}, \mathrm{Cr}, \mathrm{Cd}, \mathrm{Ni}, \mathrm{Co}, \mathrm{Mn}, \mathrm{Fe}, \mathrm{Cu}$, and $\mathrm{Zn}$ was prepared by diluting $1 \mathrm{~mL}$ of each single element of stock in the combination list to $100 \mathrm{~mL}$ with deionized distilled water. For each batch of sample in digestion process, blank solution was prepared in the identical procedure with acid (nitric acid) to ensure about that samples and chemicals used were not contaminated. Standard solution of pesticide was prepared by dissolving $10 \mathrm{mg}$ of each compound in $10 \mathrm{~mL}$ hexane and stored in amber bottles. A mixed standard solution was prepared from the individual stock solutions with a concentration of $100 \mathrm{mg} / \mathrm{L}$. A series of calibration standards were prepared by diluting $100 \mathrm{mg} / \mathrm{L}$ of the mixed standard solution to produce a final concentration of $0.005,0.05,0.02,0.01,0.1,0.2,0.5 \mathrm{mg} / \mathrm{L}$ in hexane. Stock and working solutions were stored at $4^{0} \mathrm{C}$ and used for no longer than 3 months and 1 week, respectively.

For each batch of sample in digestion process, blank solution was prepared in the identical procedure with acid (nitric acid) to ensure about that samples and chemicals used were not contaminated.

\subsection{Health Risk Calculation}

\subsubsection{Estimated Daily Intake (EDI)}

The estimated daily intake (EDI) of trace metals in fish was calculated by using metal concentration in fish muscles (wet weight basis), daily fish consumption and body weight. Following equation was used for calculation Estimated daily intake,

$$
\mathrm{EDI}=\frac{F I R \times C}{W A B}
$$

Where,

$\mathrm{C}$ is the concentration of the heavy metals in fish $\left(\mathrm{mg} \mathrm{kg}^{-1}\right)$; FIR is the daily average consumption of fish (62.58 $\mathrm{g} /$ person/day; DoF, 2018) and WAB represents the average body weight $(60 \mathrm{Kg})$.

\subsubsection{Target hazard quotient (THQ)}

The target hazard quotient (THQ) is an estimate of the dangerous level of non-carcinogenic due to pollutant exposure. According to the USEPA (1989), it is assumed that the ingestion dose is similar the adsorbed contaminant dose and that cooking doesn't alter the contaminants. In this study, the non-carcinogenic health risks related to the consumption of fish by the native inhabitants were assessed based on the target hazard quotients (THQs) and calculations were made using the standard assumption for an integrate USEPA risk analysis. 
$T H Q=\frac{E F r \times E D \times F I R \times C}{R f D \times W A B \times A T} \times 10^{-3}$

Where, THQ is the target hazard quotient, EFr is the exposure frequency (365 days/year), ED is the exposure duration (70 years), FIR is the fish ingestion rate $(62.58 \mathrm{~g} /$ person/day), $\mathrm{C}$ is the heavy metal concentration in fish muscle $(\mathrm{mg} / \mathrm{kg})$, WAB is the average body weight $(60 \mathrm{Kg})$, AT is the average exposure time for non-carcinogens (EFxED) (365 days/year for 70 years here AT = 25550 days). RfD is the reference dose of the metal (an estimate of the daily exposure to which the human population may be continuously exposed over a lifetime without an appreciable risk of deleterious effects). RfDs used for THQ calculation were: 0.0003, 0.0035, 0.003, 0.02, 0.001, 0.7, 0.04, 0.3, 0.14 for As, Pb, Cr, Ni, Cd, Fe, Cu, Zn and Mn, respectively (WHO, 2011; USEPA, 2000; 2019).

In this study, total THQ (TTHQ) was also evaluated considering the fact that humans are often exposed to more than one pollutant which can lead to combined or synergistic effects (Marengo et al., 2018). The greater the value of TTHQ, the greater the level of concern.

\subsubsection{Target cancer risk (TR)}

According to USEPA (1989), for carcinogens, risks were calculated as progressive chance of an individual to develop cancer over a lifetime exposure to that potential carcinogen. The formula which was used to calculate Target carcinogenic risk

$\mathrm{TR}=\frac{E F r \times E D \times \text { Cons } \times C \times C S F o}{B w \times A T} \times 10^{-3}$

Here, $\mathrm{CSF}_{0}$ is the oral carcinogenic factor from the Integrated Risk Information System (USEPA, 2010) database was 1.5, $8.5 \times 10^{-3}$ and $1.7(\mathrm{mg} / \mathrm{kg} /$ day) for $\mathrm{As}, \mathrm{Pb}$ and $\mathrm{Ni}$, respectively.

\section{Result And Discussion}

In this study, two organochlorine pesticides (Aldrin and Chlordane) were assessed in different fish samples imported to Bangladesh from overseas. Concentrations of the two pesticides were below the limit of detection and therefore, subsequent result and discussion will concentrate on the concentration of trace metals in fishes and associated health risk.

\subsection{Concentration of trace metals in fish muscles}

In the present study, concentration of $\mathrm{As}, \mathrm{Pb}, \mathrm{Cr}, \mathrm{Cd}, \mathrm{Ni}, \mathrm{Co}, \mathrm{Mn}, \mathrm{Fe}, \mathrm{Cu}$, and $\mathrm{Zn}(\mathrm{mg} / \mathrm{kg}-\mathrm{ww})$ were assessed in the samples of imported fishes from four countries (India, Myanmar, Oman and United Arab Emirates). Table 1 provides a summary of the mean concentrations of the trace metals in the analyzed fish samples. All metal concentrations were determined on a wet-weight basis. 
Table 1

Mean concentrations (mg/kg ww) of trace metals in muscle tissues of some fishes imported to Bangladesh from different countries.

\begin{tabular}{|c|c|c|c|c|c|c|c|c|c|c|c|}
\hline Sources & $\begin{array}{l}\text { Sample } \\
\text { name }\end{array}$ & As & $\mathrm{Pb}$ & $\mathrm{Cr}$ & Cd & $\mathrm{Ni}$ & Co & Mn & $\mathrm{Fe}$ & $\mathrm{Cu}$ & $\mathrm{Zn}$ \\
\hline \multirow[t]{2}{*}{ India } & L. rohita & 0.008 & 0.004 & 0.053 & 0.001 & 0.043 & 0.037 & 0.149 & 2.275 & 0.084 & 1.927 \\
\hline & O. ruber & 0.05 & 0.070 & 0.083 & 0.005 & 0.016 & $\mathrm{BDL}^{\mathrm{a}}$ & $\mathrm{BDL}$ & 1.895 & 0.055 & 0.898 \\
\hline \multirow[t]{5}{*}{ UAE } & $\begin{array}{l}\text { S. } \\
\text { australasicus }\end{array}$ & 0.124 & 0.065 & 0.069 & 0.074 & 0.034 & $\mathrm{BDL}$ & $\mathrm{BDL}$ & 10.77 & 0.112 & 9.245 \\
\hline & $\begin{array}{l}\text { E. } \\
\text { acuminatus }\end{array}$ & 0.148 & 0.008 & 0.053 & 0.083 & 0.03 & $\mathrm{BDL}$ & 0.291 & 7.141 & 0.632 & 4.594 \\
\hline & A. maculatus & 0.137 & 0.004 & 0.013 & 0.003 & 0.011 & $\mathrm{BDL}$ & $\mathrm{BDL}$ & 2.669 & 0.182 & 3.641 \\
\hline & T. toli & 0.558 & 0.006 & 0.109 & 0.056 & 0.059 & $\mathrm{BDL}$ & 0.718 & 9.286 & 0.495 & 6.188 \\
\hline & L. johnii & 0.022 & 0.004 & 0.01 & 0.001 & 0.023 & $\mathrm{BDL}$ & $\mathrm{BDL}$ & 2.38 & 0.199 & 3.154 \\
\hline Oman & T. toli & 0.113 & 0.010 & 0.071 & 0.015 & 0.024 & $B D L$ & 0.504 & 7.384 & 0.536 & 7.004 \\
\hline \multirow[t]{3}{*}{ Myanmar } & L. rohita & 0.013 & 0.009 & 0.049 & 0.001 & 0.011 & $\mathrm{BDL}$ & 0.126 & 2.795 & 0.218 & 2.552 \\
\hline & E. splendens & 0.034 & 0.013 & 0.017 & 0.007 & 0.044 & $\mathrm{BDL}$ & 0.456 & 1.78 & 0.106 & 2.007 \\
\hline & $\begin{array}{l}\text { C. } \\
\text { cynoglossus }\end{array}$ & 0.027 & 0.070 & 0.038 & 0.008 & 0.036 & BDL & 0.78 & 4.576 & 0.09 & 2.975 \\
\hline
\end{tabular}

Trace metal concentration varied in different fish species from $0.001-0.650 \mathrm{mg} \mathrm{kg}^{-1}$ for As, $0.002-0.073 \mathrm{mg} \mathrm{kg}^{-1}$ for $\mathrm{Pb}, 0.01-0.168 \mathrm{mg} \mathrm{kg}^{-1}$ for $\mathrm{Cr}, 0.001-0.108 \mathrm{mg} \mathrm{kg}^{-1}$ for Cd, $0.007-0.08 \mathrm{mg} \mathrm{kg}^{-1}$ for Ni, ND- $0.080 \mathrm{mg} \mathrm{kg}^{-1}$ for Co, ND$0.0780 \mathrm{mg} \mathrm{kg}^{-1}$ for $\mathrm{Mn}, 0.954-13.60 \mathrm{mg} \mathrm{kg}^{-1}$ for Fe, $0.034-0.646 \mathrm{mg} \mathrm{kg}^{-1}$ for $\mathrm{Cu}$, and $0.812-17.248 \mathrm{mg} \mathrm{kg}^{-1}$ for Zn, average of which leads to the following ranking: $\mathrm{Fe}(4.81)>\mathrm{Zn}(4.02)>\mathrm{Mn}(0.43)>\mathrm{Cu}(0.25)>\mathrm{As}(0.11)>\mathrm{Cr}(0.05)>\mathrm{Co}$ $(0.04)>\mathrm{Ni}(0.03)>\mathrm{Pb}(0.024)>\mathrm{Cd}(0.023)$.

\subsubsection{Arsenic (As)}

Arsenic concentration in the muscles of fish samples were $0.01 \pm 0.007 \mathrm{mg} \mathrm{kg}^{-1}$ in L. rohita (India); $0.05 \pm 0.01 \mathrm{mg} \mathrm{kg}^{-1}$ in 0 . ruber (India); $0.12 \pm 0.02 \mathrm{mg} \mathrm{kg}^{-1}$ in $S$. australasicus (UAE); $0.15 \pm 0.001 \mathrm{mg} \mathrm{kg}^{-1}$ in E. acuminatus (UAE); $0.14 \pm$ $0.002 \mathrm{mg} \mathrm{kg}^{-1}$ in A. maculatus (UAE); $0.56 \pm 0.09 \mathrm{mg} \mathrm{kg}^{-1}$ in $T$. toli (UAE); $0.02 \pm 0.001 \mathrm{mg} \mathrm{kg}^{-1}$ in L. johnii (UAE); $0.11 \pm$ $0.001 \mathrm{mg} \mathrm{kg}^{-1}$ in T. toli (Oman); $0.01 \pm 0.001 \mathrm{mg} \mathrm{kg}^{-1}$ in L. rohita (Myanmar); $0.03 \pm 0.002 \mathrm{mg} \mathrm{kg}^{-1}$ in E. splendens (Myanmar); $0.03 \pm 0.001 \mathrm{mg} \mathrm{kg}^{-1}$ in $C$. cynoglossus (Myanmar). This results shows that among all the fishes investigated, $T$. toli from UAE contained the highest amount of arsenic and L. rohita from India have been found to carry the minimum amount followed by L. rohita from Myanmar (Table 1). Considering the average As concentration, fish from UAE were more contaminated than fish imported from Oman, India and Myanmar (Fig. 2).

In literature, similar As accumulation level has been reported in fish from Bangladesh such as: 0.04-0.8 mg kg-1 (Islam et al., 2015), 0.077-1.486 mg kg ${ }^{-1}$ in highly consumed cultured fish (Ahmed et al., 2015), $0.139 \pm 0.00$ in L. rohita and $0.141 \pm 0.01$ in T. ilisha (Saha \& Zaman, 2013). Previous studies also reported higher arsenic content comparing to present study in fish from Bangladesh (Raknuzzaman et al., 2016; Ahmed et al., 2019; Rahman et al., 2012). Fish from 
India has been found to contain arsenic as $0.35 \pm 0.08 \mathrm{mg} \mathrm{kg}^{-1}$ in L. rohita from tropical wetlands (Kumar \& Mukherjee, 2011); $2.9 \pm 0.6 \mathrm{mg} \mathrm{kg}^{-1}$ in hilsa shad from Ganga river of India (Mohanty et al., 2017). Arsenic concentration has been recorded in higher magnitude comparing to present study in previous studies for fish from Oman (Sadeghi et al., 2019), Arabian Gulf (Kamal et al., 2015), Persian Gulf (Cunningham et al., 2019), Pakistan (Shah et al., 2009).

Arsenic is a toxic component for all living beings including human; chronic contact with which has long been found to cause lung cancer, skin carcinoma, kidney and bladder cancer, neuropathy in both the peripheral and central nervous systems (Liu et al., 2011; Medeiros et al., 2012; Kapp, 2018). The International Agency for Research on Cancer (IARC) has also classified inorganic arsenic as class 1 human carcinogen. (IARC, 2012). The maximum arsenic level permitted for fish samples is $0.10 \mathrm{mg} \mathrm{kg}^{-1}$ (FAO, 2006). The present observation showed that level of As in all fish samples from UAE (except $L$. johnii) and from Oman was higher than this proposed acceptable limit.

\subsubsection{Lead (Pb)}

Present study found the amount of $\mathrm{Pb}$ in different imported fish samples as $0.004 \pm 0.002 \mathrm{mg} \mathrm{kg}^{-1}$ in $L$. rohita (India), $0.07 \pm 0.003 \mathrm{mg} \mathrm{kg}^{-1}$ in 0 . ruber (India), $0.07 \pm 0.01 \mathrm{mg} \mathrm{kg}^{-1}$ in S. australasicus (UAE), $0.01 \pm 0.001 \mathrm{mg} \mathrm{kg}^{-1}$ in $E$. acuminatus (UAE), $0.004 \pm 0.001 \mathrm{mg} \mathrm{kg}^{-1}$ in A. maculatus (UAE), $0.01 \pm 0.001 \mathrm{mg} \mathrm{kg}^{-1}$ in L. rohita (Myanmar), $0.01 \pm$ $0.003 \mathrm{mg} \mathrm{kg}^{-1}$ in T. toli (UAE), $0.004 \pm 0.002 \mathrm{mg} \mathrm{kg}^{-1}$ in L. johnii (UAE), $0.01 \pm 0.001 \mathrm{mg} \mathrm{kg}^{-1}$ in T. toli (Oman), $0.01 \pm$ $0.001 \mathrm{mg} \mathrm{kg}^{-1}$ in E. splendens (Myanmar), $0.07 \pm 0.003 \mathrm{mg} \mathrm{kg}^{-1}$ in C. cynoglossus (Myanmar). Maximum lead content has been observed in $O$. ruber from India and $C$. cynoglossus from Myanmar and minimum was observed in $L$. rohita from India, A. maculatus from UAE, and L. johnii from UAE (Table 1). Fish from India were more contaminated with $\mathrm{Pb}$ than other samples and fish imported from Oman were with minimum concentration (Fig. 2).

Present results were almost similar to those reported earlier in fish from different regions of Bangladesh, for example, $0.07-0.63 \mathrm{mg} \mathrm{kg}^{-1}$ (Raknuzzaman et al., 2016), 0.017-0.09 mg kg-1 (Ahmed et al., 2015), 0.04-1.6 mg kg-1 (Islam et al., 2015) and also fish (Arius bilineatus) from Oman studied by Al-Busaidi et al. (2011) ranging 0.02-0.154 mg kg-1 and fish (Scomber scombrus) from Spain reported by Olmedo et al. (2013) as $0.004 \mathrm{mg} \mathrm{kg}^{-1}$. Moreover, higher level of $\mathrm{Pb}$ in comparison to present results has been observed as well in fish from Bangladesh (Saha \& Zaman, 2013; Ahmed et al., 2019; Rahman et al., 2012), India (Krishna et al., 2014; Malik et al., 2010), Oman (Sadeghi et al., 2019; Ali et al., 2013), Arabian Gulf (Kamal et al., 2015; Alizada, et al., 2020), Malaysia (Alam et al.,2012), Persian Gulf (Agah et al., 2009; Cunningham et al., 2019).

Lead is a non-essential environmental contaminant which can induce serious human health risk such as neurotoxicity, nephrotoxicity, increased risk of heart disease, decreased lung function and many other adverse health effects summarized in several reviews (Liu, et al., 2010, Medeiros et al. 2012, Cunningham, et al.2019). The maximum legislative limit for Pb specified by EU standard and Bangladesh Gazette S. R. O. No. 233-Act 2014 is $0.30 \mathrm{mg} \mathrm{kg}^{-1}$. In this study, Pb concentration in imported fish were all within this safe limit.

\subsubsection{Chromium (Cr)}

Concentrations of $\mathrm{Cr}$ were observed in the extent of: $0.05 \pm 0.02 \mathrm{mg} \mathrm{kg}^{-1}$ in $L$. rohita (India), $0.08 \pm 0.01 \mathrm{mg} \mathrm{kg}^{-1}$ in 0 . ruber (India), $0.07 \pm 0.001 \mathrm{mg} \mathrm{kg}^{-1}$ in $S$. australasicus (UAE), $0.05 \pm 0.001 \mathrm{mg} \mathrm{kg}^{-1}$ in E. acuminatus (UAE), $0.01 \pm 0.001$ $\mathrm{mg} \mathrm{kg}^{-1}$ in A. maculatus (UAE), $0.11 \pm 0.06 \mathrm{mg} \mathrm{kg}^{-1}$ in T. toli (UAE), $0.01 \pm 0.001 \mathrm{mg} \mathrm{kg}^{-1}$ in L. johnii (UAE), $0.07 \pm 0.001$ $\mathrm{mg} \mathrm{kg}^{-1}$ in T. toli (Oman), $0.05 \pm 0.001 \mathrm{mg} \mathrm{kg}^{-1}$ in L. rohita (Myanmar), $0.02 \pm 0.001 \mathrm{mg} \mathrm{kg}^{-1}$ in E. splendens (Myanmar), and $0.04 \pm 0.001 \mathrm{mg} \mathrm{kg}^{-1}$ in C. cynoglossus (Myanmar). The highest level of Cr was detected in T. toli imported from UAE followed by $O$. ruberfrom India. The lowest amount of chromium was recorded in L. johnii (UAE). Fish from India and Oman had more $\mathrm{Cr}$ in the muscle samples than fish samples imported from other countries (Fig. 2). 
Chromium concentration in literature has been documented in ranges: $1.054-1.349 \mathrm{mg} \mathrm{kg}^{-1}$ in fish from Bangladesh (Ahmed et al., 2015), 7.52-10.2 $\mathrm{mg} \mathrm{kg}^{-1}$ in 0 . ruberfrom Oman Sea, Iran (Sadeghi et al., 2019), 12-27 mg kg-1 in 0 . rubber from Persian Gulf (Agah et al., 2009), $10.4 \pm 5.3$ and $11.8 \pm 5.1 \mathrm{mg} \mathrm{kg}^{-1}$ in imported sardine and mackerel from Egypt (Abou-Arab et al., 1996), $0.96 \mathrm{mg} \mathrm{kg}^{-1}$ in L. rivulatus from India (Sankar et al., 2006).

Lower level of $\mathrm{Cr}$ corresponding to present study has also been reported in previous studies: $0.04-1.75 \mathrm{mg} / \mathrm{kg} \mathrm{ww}$ in seafood from Marmara, Aegean, and Mediterranean seas in Turkey (Turkmen et al. 2008), 0.04-1.5 mg kg-1 in fish form Bangladesh (Islam et al., 2015), $0.79 \pm 0.27$ ( $\mu \mathrm{g} / \mathrm{g}$ dry wt) in A. maculatus from Malaysia (Alam et al.,2012), $0.422 \pm 0.02$ and $0.437 \pm 0.01 \mathrm{mg} \mathrm{kg}^{-1}$ in L. rohita and hilsa shad respectively from central market of Rajshahi in Bangladesh (Saha \& Zaman, 2013), $0.219 \pm 0.008 \mathrm{mg} \mathrm{kg}^{-1}$ in muscles of L. rohita from India (Malik et al., 2010), $0.22 \mathrm{mg} / \mathrm{kg}$ in Stolephorus indicus from UAE (Alizada, et al., 2020), $0.3 \pm 0.05 \mathrm{mg} \mathrm{kg}^{-1}$ in Scomberomorus commerson (Narrow-barred Spanish mackerel) from Oman (Ali et al., 2013).

Chromium is considered as one of the 14 most toxic heavy metals (Irwin et al., 1997). Acute exposure of exceedingly high doses of chromium ( $\mathrm{VI}$ ) compounds to humans has been found to be associated with severe respiratory, neurological, cardiovascular, hematological, gastrointestinal, and renal effects (Chen et al., 2009, Carson et al., 1987). Also, numerous studies have revealed that hexavalent form of chromium can surge the odds of lung cancer (Ishikawa et al., 1994). Maximum permissible limit for $\mathrm{Cr}$ has been set as $1 \mathrm{mg} \mathrm{kg}^{-1}$ (EU, 2008); present results for $\mathrm{Cr}$ content in imported fish samples were below this limit.

\subsubsection{Cadmium (Cd)}

The level of $\mathrm{Cd}$ in studied imported fish samples was as such: $0.001 \pm 0.01 \mathrm{mg} \mathrm{kg}^{-1}$ in L. rohita (India), $0.005 \pm 0.002 \mathrm{mg}$ $\mathrm{kg}^{-1}$ in 0 . ruber (India), $0.07 \pm 0.04 \mathrm{mg} \mathrm{kg}^{-1}$ in $S$. australasicus (UAE), $0.08 \pm 0.01 \mathrm{mg} \mathrm{kg}^{-1}$ in E. acuminatus (UAE), 0.003 $\pm 0.03 \mathrm{mg} \mathrm{kg}^{-1}$ in A. maculatus (UAE), $0.06 \pm 0.02 \mathrm{mg} \mathrm{kg}^{-1}$ in T. toli (UAE), $0.001 \pm 0.002 \mathrm{mg} \mathrm{kg}^{-1}$ in L. johnii (UAE), 0.02 $\pm 0.001 \mathrm{mg} \mathrm{kg}^{-1}$ in T. toli (Oman), $0.001 \pm 0.001 \mathrm{mg} \mathrm{kg}^{-1}$ in L. rohita (Myanmar), $0.01 \mathrm{mg} \mathrm{kg}^{-1}$ in E. splendens (Myanmar), $0.01 \pm 0.001 \mathrm{mg} \mathrm{kg}^{-1}$ in C. cynoglossus (Myanmar). E. acuminatus from UAE was found to have the maximum Cd content followed by $S$. australasicus also from UAE and the minimum Cd content found in L. rohita from India and Myanmar and also L. johnii imported from UAE. In regard to the average Cd concentration in fish from different regions, fish from UAE contained the highest amount and fish from India had the minimal (Fig. 2).

Previous studies exhibited lower or equivalent $\mathrm{Cd}$ range to present study in fish from Bangladesh are: 0.001-0.003 mg $\mathrm{kg}^{-1}$ (Ahmed et al., 2015), $0.033-0.075 \mathrm{mg} \mathrm{kg}^{-1}$ in coastal areas (Raknuzzaman et al., 2016), $0.001-0.6 \mathrm{mg} \mathrm{kg}^{-1}$ (Islam et al., 2015), 0.09- $0.87 \mathrm{mg} \mathrm{kg}^{-1}$ (Rahman et al., 2012). Saha \& Zaman (2013) found higher Cd (1.365 $\left.\mathrm{mg} \mathrm{kg}^{-1}\right) \mathrm{in} \mathrm{fish}$ from central market of Rajshahi City in Bangladesh. Present study observed lower cadmium level comparing to fish form India (Krishna et al., 2014; Malik et al., 2010; Sankar et al., 2006). In case of fish from Oman, Al-Busaidi et al. (2011) found corresponding range of $\mathrm{Cd}\left(0.01-0.034 \mathrm{mg} \mathrm{kg}^{-1}\right)$ in Arius bilineatus to present study while Ali et al. (2013) found higher level of $\mathrm{Cd}\left(1.1 \pm 0.5 \mathrm{mg} \mathrm{kg}^{-1}\right)$ in Indian Mackerel (Rastrelliger kanagurta). Olmedo et al. (2013) reported 0.003$0.046 \mathrm{mg} \mathrm{kg}^{-1} \mathrm{Cd}$ in Scomber scombrus from Spain which coincides to present observations. Present study also observed similar Cd level to those reported in fish from Arabian Gulf (Kamal et al., 2015; Alizada, et al., 2020) and Turkey (Turkmen et al., 2008).

In human system $\mathrm{Cd}$ has no biological role and is a highly toxic component potential to cause chronic toxicity even with a presence of a very low concentration (Turkmen et al., 2009). Its bioaccumulation in the human body may lead to pulmonary, hepatic, skeletal, reproductive and renal effects, and even cancer (Misra et al., 1997; Baselt, 2000; Rahmani et al., 2018). Regulatory agencies such as the U.S. Department of Health and Human Services (DHHS), the International Agency for Research on Cancer (IARC) have declared Cd and its compounds as carcinogenic to human (ATSDR, 2012). 
According to EU standards and FAO/WHO, Cd concentration in fish should not exceed $0.05 \mathrm{mg} / \mathrm{kg}$ (WHO, 2011; EC, 2006). In the present study, E. acuminatus, S. australasicus and, T. toli from UAE exceeded this legislative limit.

\subsubsection{Nickel ( $\mathrm{Ni})$}

The observed level of nickel in the muscle of imported fish was as $0.04 \pm 0.02 \mathrm{mg} \mathrm{kg}^{-1}$ in L. rohita (India), $0.02 \pm 0.002$ $\mathrm{mg} \mathrm{kg}^{-1}$ in 0 . ruber (India), $0.03 \pm 0.006 \mathrm{mg} \mathrm{kg}^{-1}$ in $S$. australasicus (UAE), $0.03 \pm 0.001 \mathrm{mg} \mathrm{kg}^{-1}$ in E. acuminatus (UAE), $0.01 \pm 0.003 \mathrm{mg} \mathrm{kg}^{-1}$ in A. maculatus (UAE), $0.06 \pm 0.02 \mathrm{mg} \mathrm{kg}^{-1}$ in $T$. toli (UAE), $0.02 \pm 0.002 \mathrm{mg} \mathrm{kg}^{-1}$ in L. johnii (UAE), $0.02 \pm 0.001 \mathrm{mg} \mathrm{kg}^{-1}$ in T. toli (Oman), $0.01 \pm 0.001 \mathrm{mg} \mathrm{kg}^{-1}$ in L. rohita (Myanmar), $0.04 \pm 0.003 \mathrm{mg} \mathrm{kg}^{-1}$ in E. splendens (Myanmar), $0.04 \pm 0.002 \mathrm{mg} \mathrm{kg}^{-1}$ in C. cynoglossus (Myanmar). Highest amount of Ni was observed in T. toli (UAE) among all the fishes and the lowest nickel concentration was found in A. maculatus (UAE) and L. rohita (Myanmar). Figure 2 shows that in average Ni content were almost in similar level in imported fish muscle samples from all the regions; only fish samples from Oman amidst were in the lowest margin in terms of nickel accumulation.

As compared to present observations, earlier studies reported higher nickel accretion in fish from Bangladesh ranging: 0.04-1.4 $\mathrm{mg} \mathrm{kg}^{-1}$ (Islam et al., 2015); 0.69- $4.36 \mathrm{mg} \mathrm{kg}^{-1}$ in edible fish from Bangshi River (Rahman et al., 2012 ); 0.1 $0.56 \mathrm{mg} \mathrm{kg}^{-1}$ in commercial fish from coastal areas (Raknuzzaman et al., 2016). Higher level of Ni accumulation (3.49 \pm $0.97 \mathrm{mg} \mathrm{kg}^{-1}$ ) has also been documented in fish from India (Kumar \& Mukherjee, 2011). Sadeghi et al. (2019) found considerably elevated amount of nickel (64.45-94.71 $\left.\mathrm{mg} \mathrm{kg}^{-1}\right)$ in muscles of $O$. ruber collected from Oman Sea. Earlier studies also articulated higher Ni concentration in relation to present study in fish from Arabian Gulf (Kamal et al., 2015; Alizada et al., 2020), Persian Gulf (Agah et al., 2009; Cunningham et al., 2019). With regard to imported fish, El-Nemr (2003) found $4.73 \pm 2.85 \mathrm{mg} \mathrm{kg}^{-1}$ as average Ni concentration in imported frozen fish in Egypt which is quite higher to present study.

Nickel exists in very low levels in the environment usually but its compounds are an eminent environmental threat to human causing a variety of pulmonary adverse health effects, such as lung inflammation, fibrosis, asthma, bronchitis, emphysema and higher risk of lung and nasal cancers (ATSDR, 2005; Forti et al., 2011). Nickel and nickel compounds have been concluded as human carcinogen according to IARC working group (IARC, 1990). Values of Ni concentration in imported fish samples of present study did not exceed the maximum permissible limit for Ni set as $0.5-0.6 \mathrm{mg} \mathrm{kg}^{-1}$ in fish food (WHO, 1985).

\subsubsection{Cobalt (Co)}

In the present study, the extent of Co was only found in L. rohita from India as $0.04 \pm 0.03 \mathrm{mg} \mathrm{kg}^{-1}$ and was below the detection limit for the rest of the imported fish samples. In literature, Co concentration was reported in imported frozen fish in Egypt as ranging from below the detection limit to $17.27 \mathrm{mg} \mathrm{kg}^{-1}$ by El-Nemr (2003). Andreji et al. (2006) also recorded a minor level of Co ranging from 0.06 to $0.28 \mathrm{mg} / \mathrm{kg}$ wet weight in fish muscle collected from Lower Nitra River, Slovakia. Moreover, Co extent of current study also coincides with the observations conducted by Alizada et al. (2020) in tissues of Indian anchovy (Stolephorus indicus) from the UAE coast, Arabian Gulf where the concentration of Co was specified as below the detection limit.

Sivaperumal et al. (2007) investigated fish, shellfish and fish products from internal markets of India and documented the average Co ranged as 0.02 to $0.85 \mathrm{mg} \mathrm{kg}^{-1}$. Turkmen et al. (2008) reported the cobalt level as $0.04-0.41 \mathrm{mg} \mathrm{kg}^{-1}$ in sea food captivated from Marmara, Aegean and Mediterranean Sea. Earlier studies exhibited higher level of cobalt accumulation in fish from Persian Gulf (Agah et al., 2009; Cunningham et al., 2019), Turkey (Mendil et al., 2010), Iran (Hosseini et al., 2015) with respect to the present study. 
Cobalt in trace amount is essential nutritionally for humans and other mammals as it is a key constituent of the vitamin $B_{12}$ complex, however it has harmful health effects when taken in higher concentrations (ATSDR, 2004; Medeiros et al., 2012). Chronic exposure to Co can initiate vomiting, diarrhea, increased blood pressure, dermatitis, thyroid damage, nerve damage, severe effects on the lungs, including asthma, pneumonia (ATSDR, 2004). As information about maximum permissible limits of Co has not been designated yet in case of fish and fishery products (Rahman et al., 2012), present samples can't be stated as completely safe or not for human consumption.

\subsubsection{Manganese (Mn)}

Manganese quantity was detected as $0.15 \pm 0.12 \mathrm{mg} \mathrm{kg}^{-1}$ in $L$. rohita (India), $0.29 \pm 0.004 \mathrm{mg} \mathrm{kg}^{-1}$ in E. acuminatus (UAE), $0.72 \pm 0.28 \mathrm{mg} \mathrm{kg}^{-1}$ in T. toli (UAE), $0.5 \pm 0.02 \mathrm{mg} \mathrm{kg}^{-1}$ in $T$. toli (Oman), $0.13 \pm 0 \mathrm{mg} \mathrm{kg}^{-1}$ in L. rohita (Myanmar), $0.46 \pm 0.005 \mathrm{mg} \mathrm{kg}^{-1}$ in E. splendens (Myanmar), $0.78 \pm 0.041 \mathrm{mg} \mathrm{kg}^{-1}$ in C. cynoglossus (Myanmar). In parallel, Mn concentration was below the detection limit for O. ruber (India), S. australasicus (UAE), A. maculatus (UAE), L. johnii (NAE).

Highest level of Mn was recorded in C. cynoglossus (Myanmar) followed by $T$. toli (UAE) and the lowest was found in $L$. rohita (Myanmar). Fish samples from India contained the lowest amount of manganese followed by fish samples imported from Myanmar (Fig. 2).

Earlier analysis on Mn concentration in fish samples of Bangladesh has indicated a relatively higher extent in respect to present study (Saha \& Zaman, 2013; Rahman et al., 2012; Ahmed et al., 2015). Kumar et al. (2012) recorded $2.0 \pm 0.7 \mathrm{mg}$ $\mathrm{kg}^{-1} \mathrm{Mn}$ in hilsa shad collected from Ganga River of India. Sankar et al. (2006) studied heavy metal residues in fish and shellfish collected from Calicut region of Kerala in India and found $0.49 \mathrm{mg} \mathrm{kg}^{-1}$ manganese in muscles of Lutjanus rivulatus which coincides to the Mn level of present study. Present study also coincides with the former investigations by Ali et al. (2013) as reported $0.2 \pm 0.1 \mathrm{mg} \mathrm{kg}^{-1} \mathrm{Mn}$ in samples of Scomberomorus commerson (Narrow-barred Spanish mackerel) and Rastrelliger kanagurta (Indian Mackerel) collected from Oman and Turkmen et al. (2008) in fish from Marmara, Aegean and Mediterranean Sea. Studies on fish samples of Persian Gulf have denoted lower level of Mn as regards to the present findings (Agah et al., 2009; Cunningham et al., 2019). Higher level of Mn has also been exhibited in former investigations (El-Nemr, 2003; Islam et al., 2010; Mendil et al., 2010).

The essential trace metal, $\mathrm{Mn}$ is a cofactor for a number of enzymatic reactions and plays a pivotal role in cerebral function, in the maintenance of well-balanced nervous and immune system, blood sugar regulation, blood clotting and the formation of cartilage, bone formation, metabolism of amino acids, cholesterol and carbohydrates (Goyer and Clarkson, 2001). While insufficient intake of Mn may result in manganese deficiency leading to bone malformation and skeletal defects, heart disease, abnormal glucose tolerance, and so forth; chronic exposure to excessive levels can cause severe clinical neurological disease, and also affects the respiratory system, an inflammatory response in the lung able to induce impaired lung function over time (ATSDR, 2012). As the maximum allowable limit of $\mathrm{Mn}$ in fish and fishery products has not been set, comparison of the present findings was not conceivable in case of Mn toxicity.

\subsubsection{Iron (Fe)}

The amount of Fe was discerned in the present observation was as $2.28 \pm 1.63 \mathrm{mg} \mathrm{kg}^{-1}$ L. rohita (India), $1.9 \pm 0.14 \mathrm{mg}$ $\mathrm{kg}^{-1}$ O. ruber (India), $10.77 \pm 3.36 \mathrm{mg} \mathrm{kg}^{-1} \mathrm{~S}$. australasicus (UAE), $7.14 \pm 0.05 \mathrm{mg} \mathrm{kg}^{-1}$ E. acuminatus (UAE), $2.67 \pm 0.02$ mg kg-1 A. maculatus (UAE), $9.29 \pm 3.95 \mathrm{mg} \mathrm{kg}^{-1}$ T. toli (UAE), $2.38 \pm 0.11 \mathrm{mg} \mathrm{kg}^{-1}$ L. johnii (UAE), $7.38 \pm 0.03 \mathrm{mg} \mathrm{kg}^{-1} T$. toli (Oman), $2.8 \pm 0.04 \mathrm{mg} \mathrm{kg}^{-1}$ L. rohita (Myanmar), $1.78 \pm 0.002 \mathrm{mg} \mathrm{kg}^{-1}$ E. splendens (Myanmar), and $4.58 \pm 0.05 \mathrm{mg}$ $\mathrm{kg}^{-1}$ C. cynoglossus (Myanmar). 
Maximum amount of Iron was found in S. australasicus (UAE) and the minimal was in E. splendens (Myanmar). Considering the average amount in fish samples from different countries, fish samples imported from Oman were with the highest magnitude and fish from India were with the least amount (Fig. 2).

In comparison to present findings, relatively higher level of iron content has been reported in previous studies on fish muscles from Bangladesh as in ranging from 0.55 to $14.43 \mathrm{mg} \mathrm{Fe} / 100 \mathrm{~g}$ fish samples by Wheal et al. (2016), 31.80$296.02 \mathrm{mg} \mathrm{kg}^{-1}$ in freshwater fish of Bangladesh recorded by Sharif et al. (1993). Higher iron accumulation has also been exhibited in earlier reports in fish samples from India (Dhanakumar et al., 2015), Marmara, Aegean and Mediterranean Sea (Turkmen et al. 2008), Black sea of Turkey (Mendil et al., 2010), commonly consumed fish in Iran (Hosseini et al., 2015), frozen and canned marine fish of Korea (Islam et al., 2010). The current results of iron concentration coincide with those found in commonly consumed fish in Oman (Ali et al., 2013), fish from Red Sea and Arabian Gulf (Kamal et al. 2015), imported sardine in egypt (Abou-Arab et al., 1996), fish from Persian Gulf. (Agah et al., 2009; Cunningham et al., 2019).

Iron is an essential nutrient for all living organisms and it plays a crucial role in human health supporting oxygen binding and transport, electron transport, oxidative metabolism, DNA synthesis and cellular proliferation. (Valko et al., 2005). However, toxicological aspects are significant concerning iron deficiency, chronic iron overload and unintentional severe exposures to iron which possibly can initiate liver damage, inducing fibrosis, cirrhosis, and increased risk of hepatic cancer; iron overload also may bring about endocrinopathies and cardiac dysfunction and iron deficiency is related to anemia resulting in depleted working capacity and inhibit intellectual development (Goyer and Clarkson, 2001; Medeiros et al., 2012). The maximum permissible limit for iron concentration in fish has been set as $100 \mathrm{mg} / \mathrm{kg}$ by WHO (1989) and present findings were far beyond this safe limit.

\subsubsection{Copper (Cu)}

The mean magnitude of $\mathrm{Cu}$ in the imported fish samples were as $0.08 \pm 0.05 \mathrm{mg} \mathrm{kg}^{-1}$ L. rohita (India), $0.06 \pm 0.01 \mathrm{mg} \mathrm{kg}^{-}$ 1 O. ruber (India), $0.11 \pm 0.01 \mathrm{mg} \mathrm{kg}^{-1} \mathrm{~S}$. australasicus (UAE), $0.63 \pm 0.01 \mathrm{mg} \mathrm{kg}^{-1}$ E. acuminatus (UAE), $0.18 \pm 0.01 \mathrm{mg}$ $\mathrm{kg}^{-1}$ A. maculatus (UAE), $0.5 \pm 0.09 \mathrm{mg} \mathrm{kg}^{-1}$ T. toli (UAE), $0.2 \pm 0.02 \mathrm{mg} \mathrm{kg}^{-1}$ L. johnii (UAE), $0.54 \pm 0.01 \mathrm{mg} \mathrm{kg}^{-1} \mathrm{~T}_{\text {. toli }}$ (Oman), $0.22 \pm 0.01 \mathrm{mg} \mathrm{kg}^{-1}$ L. rohita (Myanmar), $0.11 \pm 0.02 \mathrm{mg} \mathrm{kg}^{-1}$ E. splendens (Myanmar), and $0.09 \pm 0.01 \mathrm{mg} \mathrm{kg}^{-1}$ C. cynoglossus (Myanmar).

E. acuminatus (UAE) contained highest amount of Cu content among all the imported fish samples and O. ruber (India) had the lowest level of Cu followed by L. rohita (India). Figure 2 showed that fish samples of Oman had the most copper concentration and fish samples imported from India had the minimal copper amount.

Comparatively elevated level of $\mathrm{Cu}$ in earlier studies has been recorded as ranging from $1.3-1.4 \mathrm{mg} \mathrm{kg}^{-1}$ in commercial fish and crustaceans collected from coastal area of Bangladesh (Raknuzzaman et al., 2016); 8.33- $43.18 \mathrm{mg} \mathrm{kg}^{-1}$ in edible fishes collected from Bangshi River, Dhaka (Rahman et al., 2012); 0.658-3.459 $\mathrm{mg} \mathrm{kg}^{-1}$ in cultured fish in Bangladesh (Ahmed et al., 2015); 10.27-16.41 $\mathrm{mg} \mathrm{kg}^{-1}$ in fish from Karnaphuli River estuary (Ahmed et al., 2019). Kumar \& Mukherjee (2011) investigated fish collected from Tropical Wetlands in India and found $5.30 \pm 0.31 \mathrm{mg} \mathrm{kg}^{-1} \mathrm{Cu}$ in $L$. rohita which is higher than present findings. Malik et al. (2010) found $0.398 \pm 0.002 \mathrm{mg} \mathrm{kg}^{-1} \mathrm{Cu}$ in muscles of $L$. rohita from freshwater lake of Bhopal which is similar to present results. Present results also coincide with earlier investigations of Cu in fish from Persian Gulf (Agah et al., 2009), fish from Marmara, Aegean and Mediterranean Sea (Turkmen et al., 2008). The current study found lower copper level in fish muscles with respect to those earlier reports (Krishna et al., 2014; Sadeghi et al., 2019; Ali et al., 2013; Kamal et al., 2015; Alizada et al., 2020; El-Nemr, 2003; Mendil et al., 2010). 
Copper is an essential nutrient which plays a crucial role in biological transfer of electrons and as an indispensable part of numerous metalloenzymes associated with hemoglobin formation, metabolism of carbohydrate and drug/xenobiotic, maintenance of nervous system structure and function, antioxidant defense mechanism (ATSDR, 2004; Medeiros et al., 2012). Copper deficiency can lead to blood and nervous system disorders, leukopenia, normocytic and hypochromic anemia, and osteoporosis in adults (ATSDR, 2004). Nevertheless, exposure to higher doses of copper has been disclosed to have noxious health effects. Copper accumulation has been found to be associated with hepatic cirrhosis, renal tubular damage, gastrointestinal distress, death of neurons with neurological symptoms, impaired immune system, abnormalities of the nervous system and cornea (ATSDR, 2004; Goyer and Clarkson, 2001). Copper concentration in present study was found as below the maximum allowable limit which is $30 \mathrm{mg} \mathrm{kg}^{-1}$ (FAO, 1983).

\subsubsection{Zinc (Zn)}

Zinc level was perceived in the present study as $1.93 \pm 1.09 \mathrm{mg} \mathrm{kg}^{-1}$ in $L$. rohita (India), $0.9 \pm 0.07 \mathrm{mg} \mathrm{kg}^{-1} \mathrm{mg} \mathrm{kg}^{-1}$ in 0 . ruber (India), $9.25 \pm 7.1 \mathrm{mg} \mathrm{kg}^{-1}$ in $S$. australasicus (UAE), $4.59 \pm 0.004 \mathrm{mg} \mathrm{kg}^{-1}$ in E. acuminatus (UAE), $3.64 \pm 0.85 \mathrm{mg}$ $\mathrm{kg}^{-1}$ in A. maculatus (UAE), $6.19 \pm 2.36 \mathrm{mg} \mathrm{kg}^{-1}$ in T. toli (UAE), $3.15 \pm 0.002 \mathrm{mg} \mathrm{kg}^{-1}$ in L. johnii (UAE), $7 \pm 0.1 \mathrm{mg} \mathrm{kg}^{-1}$ in T. toli (Oman), $2.55 \pm 0.14 \mathrm{mg} \mathrm{kg}^{-1}$ in L. rohita (Myanmar), $2.01 \pm 0.04 \mathrm{mg} \mathrm{kg}^{-1}$ in E. splendens (Myanmar), $2.98 \pm 0.19$ $\mathrm{mg} \mathrm{kg}^{-1}$ in C. cynoglossus (Myanmar).

The maximal Zn concentration was recorded in S. australasicus (UAE) followed by T. toli (Oman) and the minimal was found in 0 . ruber (India). Considering the original source, fish samples imported from Oman were with the highest amount of $\mathrm{Zn}$ and fish from India were with the lowest amount.

Considerably higher level of $\mathrm{Zn}$ has been noted in previous studies on fish samples from Bangladesh (Raknuzzaman et al., 2016; Rahman et al., 2012), fish collected from India (Kumar \& Mukherjee, 2011, Krishna et al., 2014), fish from Red Sea and Arabian Gulf (Kamal et al., 2015), frozen and canned marine fish of Korea (Islam et al., 2010). Several studies found similar Zn content in fish (Sankar et al., 2006, Ali et al., 2013, Alizada, et al., 2020, Agah et al., 2009, Cunningham et al., 2019, Turkmen et al. 2008). Ahmed et al. (2015) reported trace elements from highly consumed cultured fish (Labeo rohita, Pangasius pangasius and Oreochromis mossambicus) and observed lower amount of $\mathrm{Zn}\left(1.850-3.735 \mathrm{mg} \mathrm{kg}{ }^{-1}\right)$ in comparison to the present study. Malik et al. (2010) also mentioned insubstantial amount of $\mathrm{Zn}, 0.48 \pm 0.02 \mathrm{mg} \mathrm{kg}^{-1}$ in muscles of $L$. rohita sampled from freshwater lake of Bhopal, India which is comparatively lower concerning present observations.

Zinc, ubiquitous in the environment, is an essential micronutrient for rudimentary cell activities and a constitutional component of numerous proteins, including enzymes concerning cellular signaling pathways and transcription factors (Goyer and Clarkson 2001; ATSDR, 2005). Zinc deficiency results in severe health consequences such as growth retardation, poor appetite, skin changes, mental lethargy and immunological abnormalities (Ahmed et al., 2015). Even though $\mathrm{Zn}$ toxicity is rare, ingesting excessive levels considerably higher than the Recommended Dietary Allowances (RDAs) for zinc can likewise have adverse health effects. Taking too much zinc into the body through food, water, or dietary supplements for several months may lead to anemia, suppressed immunity, damage of pancreas, and decrease levels of high-density lipoprotein (HDL) cholesterol, copper deficiency, and possible genitourinary complications (ATSDR, 2005). Maximum allowable limit of zinc as set by FAO (1983) is $30 \mathrm{mg} / \mathrm{kg}$ for fish and current findings were much lower than this safe limit.

\subsection{Health Risk Assessment 3.2.1 Estimated Daily Intake}


The Estimated daily intake (EDI) values of trace metals from the consumption of imported fish are tabled and compared with the Tolerable Daily Intake (TDI) values in Table 2 to assess the risk associated with the consumption of these imported fish species. The results from Table 2 exhibited that EDI value of arsenic exceeded the limit of tolerable daily intake in the case of fish samples from UAE and also EDI values of $\mathrm{Cr}$ were higher for fish samples imported from India and Oman. These results indicate possible human health risks associated with these trace metals with the consumption of the studied fish samples. However, the EDI values of remaining trace metals ( $\mathrm{Pb}, \mathrm{Ni}, \mathrm{Cd}, \mathrm{Mn}, \mathrm{Fe}, \mathrm{Cu}$, and $\mathrm{Zn}$ ) were found as all below the tolerable limits. The EDI values were evaluated taken into account that a $60 \mathrm{~kg}$ person consumes about $62.58 \mathrm{~g}$ fish per day. Present results were slightly higher than those reported in previous literature regarding fish from Bangladesh (Ahmed et al., 2015; Saha \& Zaman, 2013; Rahman et al., 2012). Higher EDI values of trace metals in fish were also observed in earlier studies in respect to present results (Kumar \& Mukherjee, 2011; Krishna et al., 2014; Sadeghi et al., 2019).

Table 2

Comparison of the estimated daily intake (EDI) of trace metals from consumption of imported fishes in Bangladesh with the corresponding tolerable daily intake (TDI).

\begin{tabular}{|lllllllllll|}
\hline Sample Origin & As & $\mathrm{Pb}$ & $\mathrm{Cr}$ & $\mathrm{Cd}$ & $\mathrm{Ni}$ & $\mathrm{Co}$ & $\mathrm{Mn}$ & $\mathrm{Fe}$ & $\mathrm{Cu}$ & $\mathrm{Zn}$ \\
\hline India & 0.02 & 0.03 & $\mathbf{0 . 0 6}$ & 0 & 0.02 & 0.03 & 0.12 & 1.72 & 0.06 & 1.17 \\
\hline UAE & $\mathbf{0 . 1 6}$ & 0.01 & 0.04 & 0.04 & 0.03 & - & 0.42 & 5.32 & 0.27 & 4.43 \\
\hline Oman & 0.09 & 0.01 & $\mathbf{0 . 0 6}$ & 0.01 & 0.02 & - & 0.42 & 6.09 & 0.44 & 5.78 \\
\hline Myanmar & 0.02 & 0.03 & 0.03 & 0 & 0.03 & - & 0.37 & 2.52 & 0.11 & 2.07 \\
\hline TDI $(\mu \mathrm{gg} / \mathrm{kg}-\mathrm{bw} /$ day) & $0.126^{\mathrm{a}}$ & $3.57^{\mathrm{b}}$ & $0.05-2^{\mathrm{c}}$ & $0.5^{\mathrm{d}}$ & $0.3^{\mathrm{b}}$ & - & $2-5^{\mathrm{c}}$ & $12500^{\mathrm{c}}$ & $30^{\mathrm{d}}$ & $60^{\mathrm{b}}$ \\
\hline a (FAO, 2006), ${ }^{\mathrm{b}}(\mathrm{WHO}, 2011),{ }^{\mathrm{C}}(\mathrm{NRC}, 1989),{ }^{\mathrm{d}}(\mathrm{FAO}, 1983)$ & & & & & & \\
\hline
\end{tabular}

\subsubsection{Non-carcinogenic Risk}

To estimate the non-carcinogenic risk associated with the consumption of imported fishes in Bangladesh, THQs (Target Hazard Quotients) and TTHQs (Total Target Hazard Quotients) were calculated (Table 3). The acceptable guideline value for THQ is 1, as suggested by USEPA (2011). THQ values in present study were below this threshold limit for all individual trace metal indicating that exposure level to be below the reference dose and thus consumption of these imported fishes would possibly not cause any non-carcinogenic health risk. The THQ values in average for individual trace metal through consumption of these imported fishes followed the descending order of $\mathrm{Cd}>\mathrm{As}>\mathrm{Cr}>\mathrm{Zn}>\mathrm{Pb}>\mathrm{Fe}>\mathrm{Cu}>\mathrm{Mn}>\mathrm{Ni}$. The TTHQ values listed in Table 3 were also below 1 but values for fish imported from UAE and Oman were near the threshold limit implying the possibility of noncarcinogenic health concerns. Ahmed et al. (2015) studied trace elements from highly consumed cultured fish in Bangladesh and reported lower THQ values comparing present study except for the trace metal As and Cu. Saha \& Zaman (2013) also found lower THQ values associated with the consumption of fish from central market of Rajshahi City, Bangladesh in respect to present study except for the $\mathrm{Pb}$. In regard to present results, Ahmed et al. (2019) reported much lower THQ values for some commercially important fishes from a tropical river estuary of Bangladesh. 
Table 3

Target hazard quotient (THQ) and total target hazard quotient (TTHQ) associated with the consumption of imported fishes in Bangladesh.

\begin{tabular}{|lllllllllll|}
\hline Sample Origin & $\mathrm{As}$ & $\mathrm{Pb}$ & $\mathrm{Cr}$ & $\mathrm{Cd}$ & $\mathrm{Ni}$ & $\mathrm{Mn}$ & $\mathrm{Fe}$ & $\mathrm{Cu}$ & $\mathrm{Zn}$ & TTHQ \\
\hline India & 0.068 & 0.007 & 0.016 & 0.105 & 0.001 & 0.001 & 0.002 & 0.001 & 0.003 & 0.206 \\
\hline UAE & 0.466 & 0.004 & 0.012 & 0.357 & 0.001 & 0.003 & 0.007 & 0.006 & 0.013 & $\mathbf{0 . 8 6 7}$ \\
\hline Oman & 0.266 & 0.002 & 0.017 & 0.356 & 0.001 & 0.003 & 0.007 & 0.009 & 0.017 & $\mathbf{0 . 6 7 8}$ \\
\hline Myanmar & 0.058 & 0.006 & 0.008 & 0.321 & 0.001 & 0.002 & 0.003 & 0.002 & 0.006 & 0.408 \\
\hline
\end{tabular}

\subsubsection{Carcinogenic Risk}

The Target Cancer Risk (TR) of As, Pb and Ni related to the consumption of imported fish samples of Bangladesh were evaluated to assess the carcinogenic risks and were as listed in Table 4. Generally, TR values lying between $10^{-4}$ and $10^{-}$ ${ }^{6}$ are considered an acceptable range, values less than this limit are considered as negligible cancer risk and higher than this limit suggests high risk of cancer development associated with the consumption (USEPA, 2010). Present results found TR values to be within the acceptable range for $\mathrm{Pb}$ and $\mathrm{Ni}$. But for TCR values of arsenic with the consumption of imported fish from UAE and Oman exceeded the threshold limit. These results point toward a high a risk of cancer development associated with the consumption of these imported fish. In literature lower TR values for As associated to the consumption of fish comparing to present results have been reported by Saha \& Zaman (2013) and Ahmed et al. (2019).

Table 4

Target cancer risk (TR) associated with the consumption of imported fishes in Bangladesh.

\begin{tabular}{|llll|}
\hline Sample Origin & As & $\mathrm{Pb}$ & $\mathrm{Ni}$ \\
\hline India & $3.08 \mathrm{E}-05$ & $2.22 \mathrm{E}-07$ & $3.55 \mathrm{E}-05$ \\
\hline UAE & $\mathbf{2 . 1 0 E}-04$ & $1.05 \mathrm{E}-07$ & $3.77 \mathrm{E}-05$ \\
\hline Oman & $1.20 \mathrm{E}-04$ & $6.01 \mathrm{E}-08$ & $2.89 \mathrm{E}-05$ \\
\hline Myanmar & $2.62 \mathrm{E}-05$ & $1.84 \mathrm{E}-07$ & $3.65 \mathrm{E}-05$ \\
\hline
\end{tabular}

\section{Conclusion}

It can be concluded from the present investigation that imported fish samples contained higher level of As and Cd which may be related to the presence of such pollutants in the habitat of these fishes. Metal accumulation pattern depends on the species, growth rate, age of the fish and different environmental factor such as $\mathrm{pH}$, temperature, salinity etc. The concentration of two pesticides (Aldrin and Chlordane) was found as below the limit of detection (BDL). Heath risk calculation revealed higher dietary intakes in case of As and Cr. Though THQ and TTHQ were below the threshold limit, target carcinogenic risks were quite high by arsenic and nickel. At this moment as some of these pollutants found in fish muscles at a lower concentration, but in future, it may not be the case as we are not sure about the habitat of these fish how they were cultured or captured. Changes in fish culture practice or adulteration in the marketing channel may pollute the fish within a short period of time. Moreover, as Bangladesh is self-sufficient in fish production, a question may arise whether the country needs to import more fish at all. 


\section{Declarations}

\section{Ethics approval and consent to participate}

Not applicable

\section{Consent for publication}

Not applicable

\section{Availability of data and materials}

Not applicable

\section{Competing interests}

The authors declare that they have no competing interests.

\section{Funding}

The study was funded by the Ministry of Science and Technology, Bangladesh under Science and Technology Fellowship in 2019.

\section{Authors' contributions}

All authors contributed to the study conception and design. Material preparation, data collection and analysis were performed by Nusrat Jahan Avha, Md. Monirul Islam, Md. Sofiqul Islam and Md. Habibullah-Al-Mamun. The first draft of the manuscript was written by Nusrat Jahan Avha and Farhana Mostafiz and all authors commented on previous versions of the manuscript. All authors read and approved the final manuscript.

\section{Acknowledgements}

The authors gratefully acknowledge the Bangladesh Council of Scientific and Industrial Research for providing necessary laboratory and instrumental facilities for this study. Furthermore, authors are thankful for the kind help from the staffs of the land port authorities during sample collection.

\section{References}

1. Agah H, Leermakers M, Elskens M, Fatemi S, Baeyens W (2009) Accumulation of trace metals in the muscle and liver tissues of five fish species from the Persian Gulf. Environ Monit Assess 157:499-514

2. Ahmed MK, Shaheen N, Islam MS, Habibullah-Al-Mamun M, Islam S, Mohiduzzaman M, Bhattacharjee L (2015) Dietary intake of trace elements from highly consumed cultured fish (Labeo rohita, Pangasius pangasius and Oreochromis mossambicus) and human health risk implications in Bangladesh. Chemosphere 128:284-292 
3. Ahmed ASS, Sultana S, Habib A, Ullah H, Musa N, Hossain MB, Rahman M, Sarker M (2019) Bioaccumulation of heavy metals in some commercially important fishes from a tropical river estuary suggests higher potential health risk in children than adults. PLoS 14, 1-21

4. Alam L, Abd. Rahim Mohamed C, Bin Mokhtar M (2012). Accumulation pattern of heavy metals in marine organisms collected from a coal burning power plant area of Malacca Strait. ScienceAsia 38(4), 331.

5. Al-Busaidi M, Yesudhason P, Al-Mughairi S, Al-Rahbi WAK, Al-Harthy KS, Al-Mazrooei NA, Al-Habsi SH (2011) Toxic metals in commercial marine fish in Oman with reference to national and international standards. Chemosphere 85(1):67-73.

6. Ali A, Al-Abri ES, Goddard JS, Ahmed SI (2013) Seasonal variability in the chemical composition of ten commonly consumed fsh species from Oman. J Anim Plant Sci 23:805-812

7. Alizada N, Malik S, Muzaffar SB (2020) Bioaccumulation of heavy metals in tissues of Indian anchovy (Stolephorus indicus) from the UAE coast, Arabian Gulf. Marine Pollution Bulletin 154:111033.

8. Andreji J, Stranai I, Massanyi P, Valent M (2006) Accumulation of Some Metals in Muscles of Five Fish Species from Lower Nitra River, Journal of Environmental Science and Health, Part A 41(11):2607-2622.

9. ATSDR (2005) Toxicological Profile for Nickel. Agency for Toxic Substances, Disease Registry, US Department of Health and Human Services, Public Health Service, Atlanta, GA.

10. ATSDR (2004) Toxicological profile for cobalt. Agency for Toxic Substances and Disease Registry, U.S. Department of Health and Human Services, Public Health Service. Atlanta, GA.

11. ATSDR (2004) Toxicological profile for Copper. Agency for Toxic Substances and Disease Registry, U.S. Department of Health and Human Services, Public Health Service. Atlanta, GA.

12. ATSDR (2005) Toxicological profile for Zinc. Agency for Toxic Substances and Disease Registry, U.S. Department of Health and Human Services, Public Health Service. Atlanta, GA.

13. ATSDR (2012) Toxicological Profile for Cadmium. Atlanta, GA: Agency for Toxic Substances and Disease Registry, U.S. Department of Health and Human Services, Public Health Service. Atlanta, GA.

14. ATSDR (2012) Toxicological profile for Manganese. Agency for Toxic Substances and Disease Registry, U.S. Department of Health and Human Services, Public Health Service. Atlanta, GA.

15. Baselt RC (2000) Disposition of Toxic Drugs and Chemicals in Man. $5^{\text {th }}$ Ed.. Foster City, CA: Chemical Toxicology Institute.

16. Carson BL, Ellis HV, McCann JL (1987)Toxicology and Biological Monitoring of Metals in Humans, Lewis Publishers, Chelsea, Michigan

17. Chen TL, Wise SS, Kraus S, Shaffiey F, Levine K, Thompson DW, Romano T, O’Hara T, Wise JP (2009) Particulate hexavalent chromium is cytotoxic and genotoxic to the North Atlantic right whale (Eubalaena glacialis) lung and skin fibroblasts. Environ Mol Mutagenesis 50:387-393

18. Chen S, Yu X, He X, Xie D, Fan Y, Peng J (2009) Simplified pesticide multi residues analysis in fish by low-temperature cleanup and solid-phase extraction coupled with gas chromatography/mass spectrometry. Food Chem 113(4):1297-1300

19. Cunningham PA, Sullivan EE, Everett KH, Kovach SS, Rajan A, Barber MC (2019) Assessment of metal contamination in Arabian/Persian Gulf fish: a review. Mar Pollut Bull 143:264-283

20. Dhanakumar S, Solaraj G, Mohanraj R (2015) Heavy metal partitioning in sediments and bioaccumulation in commercial fish species of three major reservoirs of river Cauvery delta region, India. Ecotoxicol Environ Saf 113:145-151.

21. DoF (2018) Yearbook of Fisheries Statistics of Bangladesh, 2017-18. Fisheries Resources Survey System (FRSS), Department of Fisheries. Bangladesh: Ministry of Fisheries, Volume 35: p. 129.

Page 16/21 
22. EC (2006) Setting Maximum Levels for Certain Contaminants in Foodstuffs, European Commission, Regulation (EC) No. 1881/2006, L 364/5-L 364/24.

23. El-Nemr A (2003) Concentrations of certain heavy metals in imported frozen fish in Egypt. Egpyt J Aquat Biol Fish 7:139-154.

24. EU (2008) Commission regulation (EC) No. 629/2008 of 2 July 2008 amending regulation (EC) No. 1881/2006 setting maximum levels for certain contaminants in foodstuffs. Off. J. Eur. Union L 173, 6-9.

25. FAO (1983) Compilation of legal limits for hazardous substances in fish and fishery products. FAO Fishery Circular No. 464, 5-10. Food and Agriculture Organization of the United Nations, Rome.

26. FAO (2006) Arsenic contamination of irrigation water, soil and crops in Bangladesh: Risk implications for sustainable agriculture and food safety in Asia. Food and Agriculture Organization of the United Nations Regional Office for Asia and the Pacific, Bangkok, Thailand

27. FAO (2018) The State of World Fisheries and Aquaculture 2018 - Meeting the sustainable development goals. Rome. Licence: CC BY-NC-SA 3.0 IGO.

28. Forti E, Salovaara S, Cetin Y, Bulgheroni A, Pfaller RW, Prieto P (2011) In vitro evaluation of the toxicity induced by nickel soluble and particulate forms in human airway epithelial cells. Toxicol in Vitro 25:454-461.

29. Goyer RA, Clarkson TW (2001) Toxic effects of metals. In: Klaassen CD (ed) Cassarett and Doull's toxicology: the basic science of poisons. McGraw-Hill, New York, NY, pp 811-867

30. Hosseini M, Nabavi SMB, Nabavi SN, Pour NA (2015) Heavy metals (Cd, Co, Cu, Ni, Pb, Fe, and Hg) content in four fish commonly consumed in Iran: risk assessment for the consumers. Environ Monit Assess 187 (5), 237.

31. IARC (2012) A Review of Human Carcinogens: Arsenic, Metals, Fibres, and Dusts, vol. 100c. International Agency for Research on Cancer, Lyon, France, pp. 41-93.

32. IARC (1990) IARC monographs on the evaluation of carcinogenic risks to humans. Volume 49: Chromium, nickel and welding. Lyon, France: International Agency for Research on Cancer, World Health Organization, 257-445

33. Ishikawa Y, Nagakawa K, Satoh Y, Kitagawa T, Sugano H, Hirano T, Tsuchiya E (1994) Characteristics of chromate workers' cancers, chromium lung deposition and precancerous bronchial lesions: an autopsy study. Braz J Cancer 70:160

34. Islam MS, Ahmed MK, Habibullah-Al-Mamun M (2015) Determination of heavy metals in fish and vegetables in Bangladesh and health implications. Human Ecol Risk Assess 21:986-1006

35. Kamal KT, Lotfi K, Omar KD, Mohamed RE, Abueliz KM, Nassir H (2015) Heavy metals concentrations in fish from Red Sea and Arabian Gulf: health benefits and risk assessments due to their consumption. Asian J Chem 27(12):4411-4416

36. Kapp RW (2018) Arsenic Toxicology. Ref Mod Biomed Sci, Elsevier, ISBN 9780128012383, https://doi.org/10.1016/B978-0-12-801238-3.62151-7.

37. Krishna P V, Jyothirmayi V, Rao K M (2014) Human health risk assessment of heavy metal accumulation through fish consumption, from Machilipatnam Coast, Andhra Pradesh, India. Int Res J Public Environ Health 1(5):121-125

38. Kumar B, Mukherjee D P (2011) Assessment of human health risk for arsenic, copper, nickel, mercury and zinc in fish collected from tropical wetlands in India. Adv Life Sci Technol 2:13-24

39. Liu LZ, Jiang Y, Carpenter RL, Jing Y, Peiper SC, Jiang BH (2011) Role and mechanism of arsenic in regulating angiogenesis PLoS One, 6:e20858, https://doi.org/10.1371/journal.pone.0020858

40. Malik N, Biswas AK, Qureshi TA et al. (2010) Bioaccumulation of heavy metals in fish tissues of a freshwater lake of Bhopal. Environ Monit Assess 160:267.

41. Marengo M, Durieux EDH, Ternengo S, Lejeune P, Degrange E, Pasqualini V, Gobert S (2018) Comparison of elemental composition in two wild and cultured marine fish and potential risks to human health. Ecotox Environ Safe 158:204- 
212.

42. Medeiros RJ, dos Santos LMG, Freire AS, Santelli RE, Braga AMC, Krauss TM, Jacob SDC (2012) Determination of inorganic trace elements in edible marine fish from Rio de Janeiro State, Brazil. Food Control 23:535-541

43. Mendil D, Demirci Z, Tuzen M, Soylak M (2010) Seasonal investigation of trace element contents in commercially valuable fish species from the Black sea, Turkey. Food Chem Toxicol 48:865-870.

44. Misra RR, Crance KA, Bare RM, Waalkes, MP (1997) Lack of correlation between the inducibility of metallothionein mRNA and metallothionein protein in cadmium-exposed rodents. Toxicology 117:99-109

45. Mohanty BP, Ganguly S, Mahanty A, Mitra T, Paria P, Behera BK, Das BK (2017) Estimation of arsenic and mercury in fishes from river Ganga for riverine ecosystem health biomonitoring and assessment. J Inland Fish Soc India 49(1):48-56

46. NRC (1989) Recommended dietary allowances, National Research Council (US) sub-committee. Washington: National Academy Press.

47. Olmedo P, Pla A, Hernandez AF, Barbier F, Ayouni L, Gil F (2013) Determination of toxic elements (mercury, cadmium, lead, tin and arsenic) in fish and shellfish samples. Risk assessment for the consumers. Environ Int 59:63-72

48. Rahman MS, Molla AH, Saha N, Rahman A (2012) Study on heavy metals levels and its risk assessment in some edible fishes from Bangshi River, Savar, Dhaka, Bangladesh. Food Chem 134(4):1847-1854.

49. Rahmani J, Fakhri Y, Shahsavani A, Bahmani Z, Urbina MA, Chirumbolo S, Keramati H, Moradi B, Bay A, Bjørklund G (2018) A systematic review and metaanalysis of metal concentrations in canned tuna fish in Iran and human health risk assessment. Food Chem Toxicol 118:753-765

50. Raknuzzaman M, Ahmed MK, Islam MS, Habibullah-Al-Mamun M, Tokumura M, Sekine M, Masunaga S (2016) Trace metal contamination in commercial fish and crustaceans collected from coastal area of Bangladesh and health risk assessment. Environ Sci Pollut Res 23(17):17298-17310.

51. Sadeghi P, Loghmani M, Afsa E (2019) Trace element concentrations, ecological and health risk assessment in sediment and marine fish Otolithes ruber in Oman Sea, Iran. Mar Pollut Bull 140:248-254

52. Saha N, Mollah MZI, Alam MF, Rahman MS (2016) Seasonal investigation of heavy metals in marine fishes captured from the Bay of Bengal and the implications for human health risk assessment. Food Control 70:110-118.

53. Saha N, Zaman MR (2013) Evaluation of possible health risks of heavy metals by consumption of foodstuffs available in the central market of Rajshahi City, Bangladesh. Environ Monit Assess 185:3867-3878

54. Sankar TV, Zynudheen AA, Anandan R, et al. (2006) Distribution of organochlorine pesticides and heavy metal residues in fish and shellfish from Calicut region, Kerala, India. Chemosphere 65:583-90.

55. Shah AQ, Kazi TG, Arain MB, Jamali MK, Afridi HI, Jalbani N, Baig JA, Kandhro GA (2009) Accumulation of arsenic in different fresh water fish species-potential contribution to high arsenic intakes. Food Chem 112:520-524.

56. Sharif AKM, Alamgir M, Mustafa Al, Hossain MA, Amin MN (1993) Trace element concentrations in ten species of freshwater fish of Bangladesh. Sci Tot Environ 138(1-3):117-126

57. Sivaperumal P, Sankar TV, Nair PGV (2007) Heavy metal concentrations in fish, shellfish and fish products from internal markets of India vis-à-vis international standards. Food Chem 102:612-620

58. Thiyagarajan D, Dhaneesh KV, Kumar TTA, Kumaresan S, Balasubramanian T (2012) Metals in fish along the southeast coast of India. Bul Environ Contam Toxicol 88:582-588

59. Turkmen M, Turkmen A, Tepe Y, Ates A, Gokkus K (2008) Determination of metal contaminations in sea foods from Marmara, Aegean and Mediterranean seas: twelve fish species. Food Chem 108:794-800.

60. USEPA (1989) Risk Assessment Guidance for Superfund, Volume I: Human Health Evaluation Manual (Part A), Interim Final. The United States Environmental Protection Agency 540/1-89/002, Washington DC, USA. 
61. USEPA (2000) Risk Assessment and Fish Consumption Limits. Ill Edition. The United States Environmental Protection Agency, EPA 823-B-00-008. USA, Office of Water, Washington DC.

62. USEPA (2019) Risk Based Concentration Table; United States Environmental Protection Agency: Philadelphia. PA, USA; Washington, DC, USA.

63. USEPA (2010) Risk-Based Concentration Table. <http://www.epa.gov/reg3hwmd/risk/human/index.htm>.

64. Valko MMHCM, Morris H, Cronin MTD (2005) Metals, toxicity and oxidative stress. Curr Med Chem 12(10):11611208

65. Wheal MS, DeCourcy-Ireland E, Bogard JR, Thilsted, SH, Stangoulis JCR (2016) Measurement of haem and total iron in fish, shrimp and prawn using ICP-MS: Implications for dietary iron intake calculations. Food Chem 201:222-229

66. WHO (2011) Safety evaluation of certain food additives and contaminants, WHO food additives series: 64, Lead (pages 381-497), World Health Organization, Geneva.

67. WHO (1985) Guidelines for the Study of Dietary Intakes of Chemical Contaminants. World Health Organization, Geneva (Switzerland), pp. 20-23

68. WHO (1989) Environment Health Criteria. Heavy metals-environmental aspects, World Health Organization, Geneva, Switzerland.

\section{Figures}




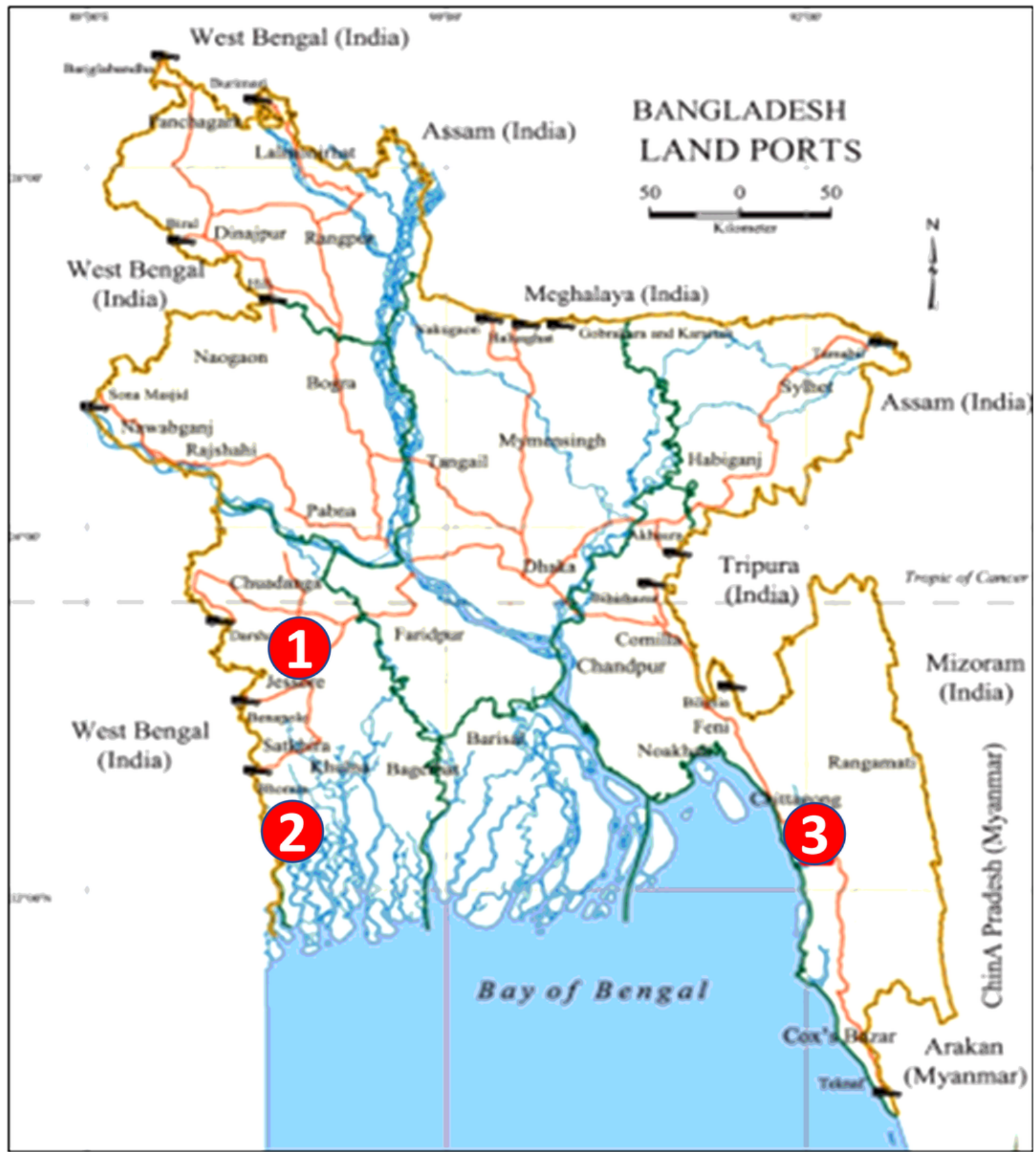

Figure 1

Map showing the location of land ports (1-Benapole, 2-Bhomra, and 3-Chittagong) from where the imported fish samples were collected. 


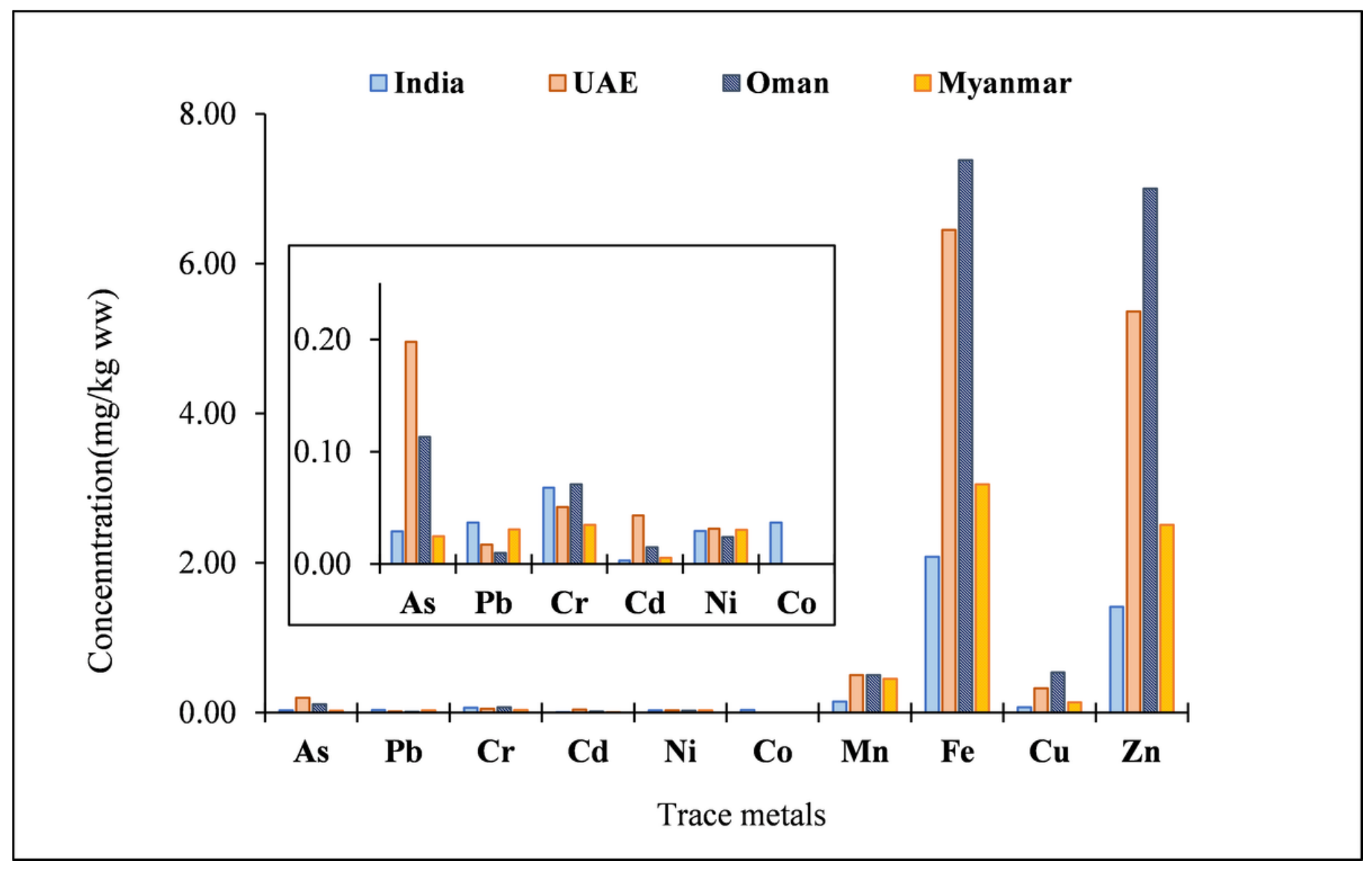

Figure 2

Concentrations of trace metals ( $\mathrm{mg} / \mathrm{kg} w \mathrm{w}$ ) in imported fishes in Bangladesh. 